\title{
各種合釘形態が支台雨根に及ぼす 影響に関する力学的研究
}

\author{
中 沢 靖* 村岡清孝* 横山建 介** \\ 中林靖夫* 高木勝憲** 中川英介*
}
Dynamic Studies on the Influence of Abutment root by Using Various Types of Post

\author{
Yasushi Nakazawa, Kiyotaka Muraoka, Kensuke Yokoyama, \\ Yasuo Nakabayashi, Masanori Takagi, Eisuke Nakagawa
}

\section{I. 緒 言}

近年, Porcelain jacket crown, Porcelain fused to metal crown の目ざましい進歩発達に伴い, 前菌部無 髄歯に Cast core を用いる補猁処置法は, 日常臨床の 常道となってきた.

一方, 合釘に関する研究業績は数多く見られるが, 合 釘の長さ，太さ，形態などに関する蹦木指針となり得る 科学的根拠を示すものは少ない. Koller ${ }^{1)}$ は合釘の長さ， 太さ, Ackerman 2) は合釘の縦断面形態についてある程 度の示唆を与えているが, 単なる計算値から割り出して いるため，そのまま臨床に応用しうるかどうかは疑問で ある. 下総3) や稲葉4は，正常な歯においては歯の長軸 の回転中心が歯根の $1 / 2$ よりわずかに根尖奇りにあると し，合釘の長さは歯根長の $2 / 3$ の長さが必要であるとし ている. Stern ${ }^{5)}$ は経験的に見た歯の破折線の状態か ら，合釘の先端は少なくとも根尖と歯槽骨頂縁との $1 / 2$ より根尖寄りに長くしなければならないとしている. 維 持力の観点から Colley ら ${ }^{6}$ や花村7) は引張り試験を行 ない，合釷は長いほど, taper 度は小さいほど良いとい う結論を出している. 天野8)はストレンゲージを用いて， 合釘の長さおよび形態と根面に加わる咬合力との関係を

* 日本大学歯学部補緅学教室（主任：中沢靖教授）

** 日本大学大学院齿学研究科補緅学専攻

* Nihon University, Dept. of Prosthodontics (Chief : Prof. Yasushi Nakazawa)

** Nihon University Graduate School of Dentistry, Major in Prosthodontics 昭和 49 年 4 月 22 日受付
報告し，出井9) は二次元光弹性実験，宫内 ${ }^{10)}$ は三次元光 弾性実験を行ない，継続歯の応力の分布状態を観察して いる. また, Standlee ら ${ }^{11)}$ は二次元光弾性実験により， 合釘の形態，長さの変化による応力の分布状態を比較検 討しており，基礎的研究として大いに評価されるが，半 無限板を用いた実験であるため歯根といら有限体内での 合釘の影響をつぶさに知ることはできない.

このように, 過去の研究報告には合釘を臨床上いかに 与えたら最を好ましいかという科学的根拋が少ないにも かかわらず,いつしかわれわれの脳裡には歯根長の $2 / 3$, 歯根幅の $1 / 3$, 絶断面形態は parallel に近い円錐形, 横 断面形態は卵中形ないしは棈円形という基準ができ上つ てしまい，当然の公理として盲目的に従つているという のが現状であろう.

そこで著者らは，エポキシ樹脂板に定形と思われる解 剖学的な歯根形態を可及的に付与し，なお，合釘先端部 の形態として角状および丸状, 合釘の長さとして歯根長 の $1 / 2,2 / 3,3 / 4$, 合釘の太さとして歯根幅の $1 / 4,1 / 3$, 1/2 のそれぞれの合釘を挿入した実験模型を作製し、 二 次元光弾性実験により各々の応力の分布状態を比較検郡 し, 力学的立場から菌根といら有限体の中で最も好まし い合釘の形態および寸法（合釘先端部の角状および丸 状, 長さ, 太さ) を探索, 追究した.

\section{II. 材料および実験方法}

\section{1. 実験装置}

実験装置は, 理研計器社製の光弾性実験装置ならびに 


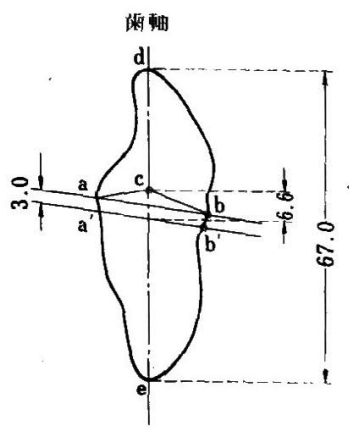

$\mathrm{a}^{\prime} \mathbf{b}^{\prime}$ : 解剖学的菊頸

$\mathrm{ab}:$ 歯肉縁下 $0.5 \mathrm{~mm}$ 相当部

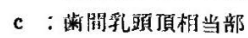

d : 切緣

e ：根尖端

de：歯軸

単位 $(\mathrm{mm})$

図 1 模型基本原図

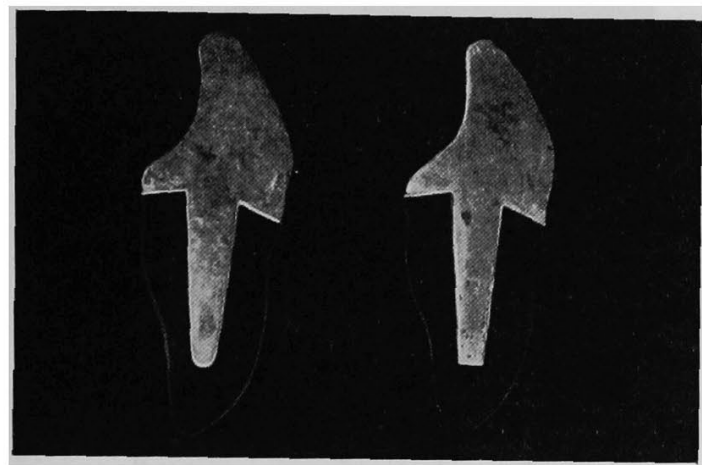

図 3 R. type と S. type の奏験模型

応力凍結用恒温槽を用いた.

\section{2. 実験模型}

実験模型は, 上顎右側中切歯で解剖学的定形12) と思わ れる健常抜去歯を選定し，切端中央と歯根端を通り，な お，かつ近遠心径 $1 / 2$ を通る研摩標本を製作し，等長写 真撮影後 3 倍大に拉大し原型とした. これをトレースし た後, 図 1 に示すような各基準線を付与し, 原図とした。 歯根幅は $a b$ とし，歯根長は歯軸と $a b$ との交点から根 尖までの長さとした. 各支台模型はエポキシ樹脂 $6 \mathrm{~mm}$ 板 (理研計器社製) にあらかじめセルロイドで作つた原 板を当てて黑描きし，切り抜いた．なお，根面形態は村 岡13,14）を参考とし両斜面形態とした. 合釘の taper 度 は1/10 とし, 太さは $a b$ 上の長さをもつて示した. 予備 実験として合釘先端部の形態の影響を見るため, 太さは 歯根幅の $1 / 3$, 長さは歯根長の $2 / 3$ の合釘 (以下 $1 / 3$ 径, $2 / 3$ 長の合釘と略す）の先端が，図 2 に示すように角状 の Square type (以下 S. type と略) と丸状の Round type (以下 R. type と略) の 2 種を作製した (図3).

R. type の設定に際しては，合釘の長さを変えずかつ合 釷の両側面の長さを可及的に損わないよう配虑し, 作図

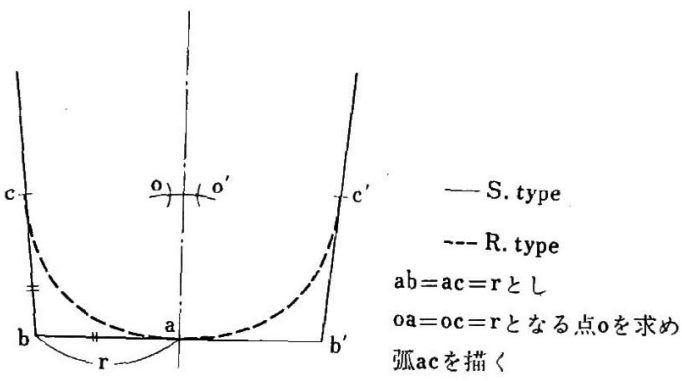

図 2 R. type の設定法

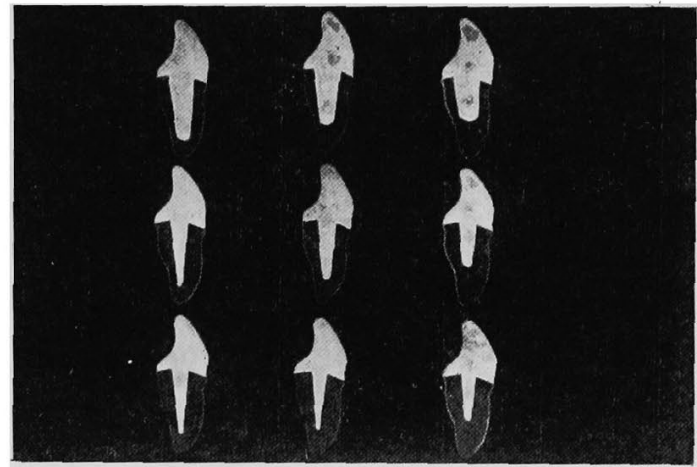

図 4 R. type の各種寸法の実験模型

により円の中心 $\mathrm{OO}^{\prime}$ を求め, それぞれ孤 $\mathrm{ac}, \mathrm{ac}^{\prime}$ を描い た. さらに, $1 / 4,1 / 3,1 / 2$ 径, $1 / 2,2 / 3,3 / 4$ 長につ いてそれぞれ 3 種計 9 個の R. type の合釘を装着した模 型を作製した (図 4 ). 合釘と歯冠部は, $E=12,300 \mathrm{~kg} /$ $\mathrm{mm}^{2}$ の合金にて通法に従い鋳造作製した. 支台歯根部 周囲には, 今村15)による歯根模の厚さを参考にし, その 3 倍の約 $0.8 \mathrm{~mm}$ の $\mathrm{G}-\mathrm{C}$ 社製シリコーンラバー $(\mathrm{E}=$ $13.5 \mathrm{~kg} / \mathrm{mm}^{2}$ ) を貼り人工歯根膜とした. これらの模型 を支える歯槽㸗相当部を有するブロックを超硬石高で作 製し, 歯軸と荷重方向が $45^{\circ}$ になるようにした. 支台模 型は恒温槽にてアニリングを行ない, 模型作製途上の残 留応力, 時間縁効果を除去し, 初期応力の起こらないよ うに注意しながら合釘をセメント合着し, 歯槽裔相当部 に植立した.

\section{3. 実験方法}

完成した実験模型を光弾性実験装置の荷重装置に位置 と方向とを正確に設置した. 荷重は歯軸に対し $45^{\circ}$ 方向 から静的荷重を行ない, 荷重量は $21.5 \mathrm{~kg}$ とした. 荷重 によって模型内に発生した灾力の分布状態を等色線縞写 真撮影を行ない，周辺応力分布図を作製した.なお，本 実験に際し，自然歯，菌周組織の棈成ならびに物理学的 性質を考虑外に㯰き，均質体とみなして実験を行なつ た. 主応力差の值を知るための試験材料の光弾性定数の 
表 $11 / 3$ 径 2/3長の S. type とR. type の比較

\begin{tabular}{c|c|c}
\hline & S. type & R. type \\
\hline A & 6 & 4 \\
\hline B & 7 & 7 \\
\hline C & 3.5 & 4 \\
\hline
\end{tabular}

$A ：$ 合釷周辺の舌側下部

$\mathrm{B} ：$ 㐘根周囲の唇側歯頸部付近

$\mathrm{C} ：$ 唇側の支台歯根面

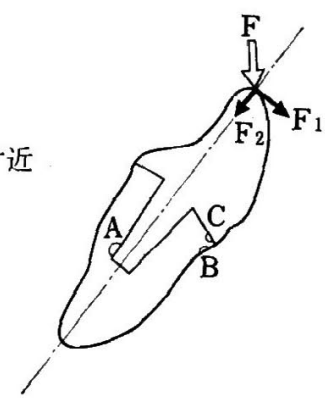

図 5 各種合钉の最大縞次数の比較部位

$\mathrm{F}$ ：荷重

$\mathrm{F}_{2}$ ：歯軸に直角方向の分力

$\mathrm{F}_{2}:$ 歯軸方向の分力

曲げ試験による検定の結果は，1 フリンジオーダー（以 下 $\mathrm{f}_{0}$ と略) $0.22 \mathrm{~kg} / \mathrm{mm}^{2}$ であつた. 解析法は辻ら ${ }^{16)}$ に 従つた.

\section{III. 実験成 績}

各々の模型に外力を加えた時の周辺応力分布状態は, それぞれほぼ同傾向であり，合釘と唇側歯槽骨相当部か らの圧縮によつて惹起される歯根周囲の唇側歯頸部付近 の強、応力集中, 合釘長軸の平面内の回転によるはね上 がりによつて惹起される合釷周辺の舌側下部の強い応力 集中, さらに歯軸方向への合釷の推進ならびに回転阻止 のため绕じる唇側の支台㧘根面にも応力が発生し, 舌 側の支台歯根面ならびに舌側蔽根上部にはほとんど忍力 分布が認められない。このような応力分布状態は村岡 ${ }^{133}$ の実験成績と同様のパターンを示している．したがつ て, 著者らは各々の模型の応力分布状態を解析, 検討す るに当たり, 特に応力集中が強く, 構造力学上問題とな りそうな䇫所を選定し，以下比較検討していくことにす る. その比較部位は図 5 のごとく 3 カ所とし，以下記号 をって記述していく.

\section{S. type と R. type との比較}

まず予備実験として合猃先端の形状の差異による影響 を検討するために，臨床上一般に行なわれている $1 / 3$
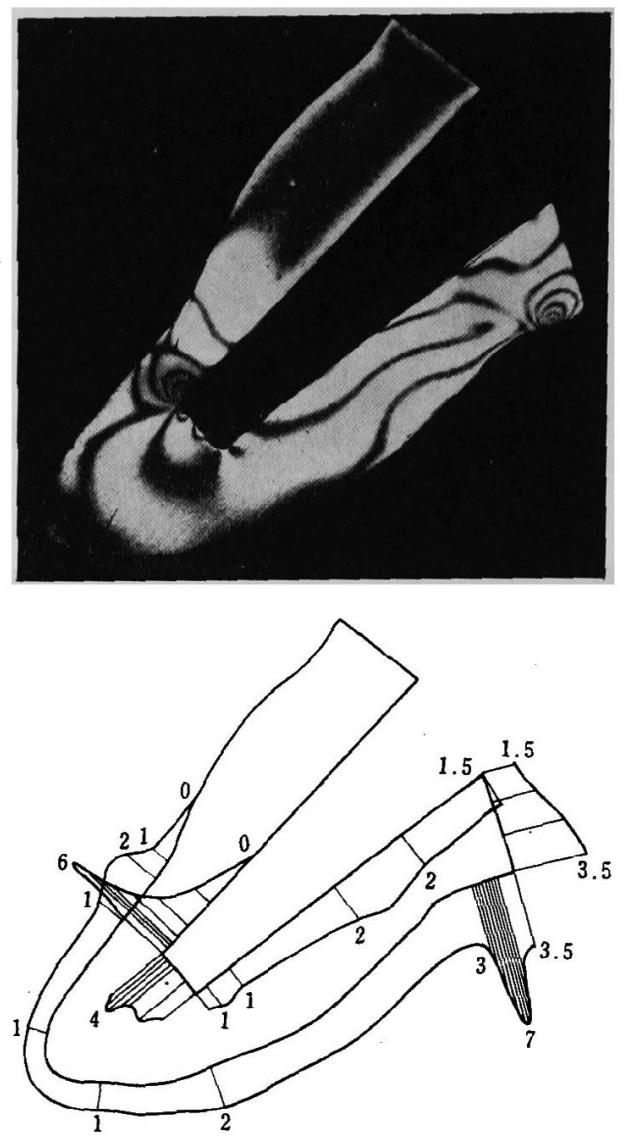

図 $61 / 3$ 径 $2 / 3$ 長のS. type の合釘の等色線縞写真 （上）とその周辺応力分布図（下）

径, $2 / 3$ 長の各 type の合釘を比較した。各比較部位の 最大縞次数を表 1 に示した. S. type では,図 6 に示すご とくAには $\mathrm{f}_{0} 6$ の強い応力集中がみられ，B に注 $\mathrm{f}_{0} 7$ ， $\mathrm{C}$ には $\mathrm{f}_{0} 3.5$ であり, R. type では図 11 に示すごとく A に $\mathrm{f}_{0} 4$ ，Bには $\mathrm{f}_{0} 7, \mathrm{C}$ に注 $\mathrm{f}_{0} 4$ であつた. S. type, R. type ともに B，C ではほぼ同じであるが，A におい ては S. type は R. typeの 1.5 倍の応力集中がみられ， 歯根破折の危険性が大である. 合釘の回転防止には,

R. type より S. type の方が有効であろうということ が容易に想像されるが, 両者の B，C の応力分布状態を 比較するとほとんど差は見られない。すなわち, R. type の方が S. type より多く回転しているとすれば，当然 B とCにより大きな応力集中が見られなければならない が，両者㲹差がないということは，同一径，同一長の合 釘では，先端の形状は回転防止に何ら影響を与えていな いことになる.Aにおける歯根破折の危險性を考える 
铱 2 各程合釘の各比较部位における最大縞次数

\begin{tabular}{|c|c|c|c|c|c|c|c|c|c|c|}
\hline \multirow{2}{*}{ 長 } & \multirow{2}{*}{ 径 } & \multicolumn{3}{|c|}{$1 / 2$} & \multicolumn{3}{|c|}{$1 / 3$} & \multicolumn{3}{|c|}{$1 / 4$} \\
\hline & & A & B & C & A & B & C & A & B & C \\
\hline \multirow{3}{*}{$1 / 2$} & A & 3 & & & 8 & & & 7 & & \\
\hline & B & & 13 & & & 8.5 & & & 9 & \\
\hline & C & & & 5 & & & 9 & & & 5 \\
\hline \multirow{3}{*}{$2 / 3$} & A & 3 & & & 4 & & & 6 & & \\
\hline & B & & 15 & & & 7 & & & 6 & \\
\hline & C & & & 3 & & & 4 & & & 3 \\
\hline \multirow{3}{*}{$3 / 4$} & $\mathbf{A}$ & 5 & & & 5 & & & 4 & & \\
\hline & B & & 12 & & & 11 & & . & 9 & \\
\hline & C & & & 5 & & & 6 & & & 5 \\
\hline
\end{tabular}

と，いたずらに䛊つた概念で，合釘先端の形態を角状 (S. type) にしてはならないと言える. 合釘の条件が同 一ならば，先端の形態は丸状の方が好ましい応力分布を 呈することが判明したので，以下 R. type の合釘を用 い, 長さ 3 種, 太さ 3 種計 9 個の模型にて行なつた実験 成績について述へることにする.

2. 長さ，太さを変えた各種合釘の比较

各種合釘の各比較部位の最大縞次数を表 2 に示した. また, 合猃の長さの変化による各比較部位の最大縞次 数の影箁を表 3 に示し, 太さの変化による各比較部位の 最大縞次数の影響を表 4 に示した。

(1) $1 / 2$ 径 $1 / 2$ 長

図 7 のごとく, A には $\mathrm{f}_{0} 3, \mathrm{~B}$ には $\mathrm{f}_{0} 13, \mathrm{C}$ には $\mathrm{f}_{0} 5$ であり, 特に Bの応力集中が強い。

表 3

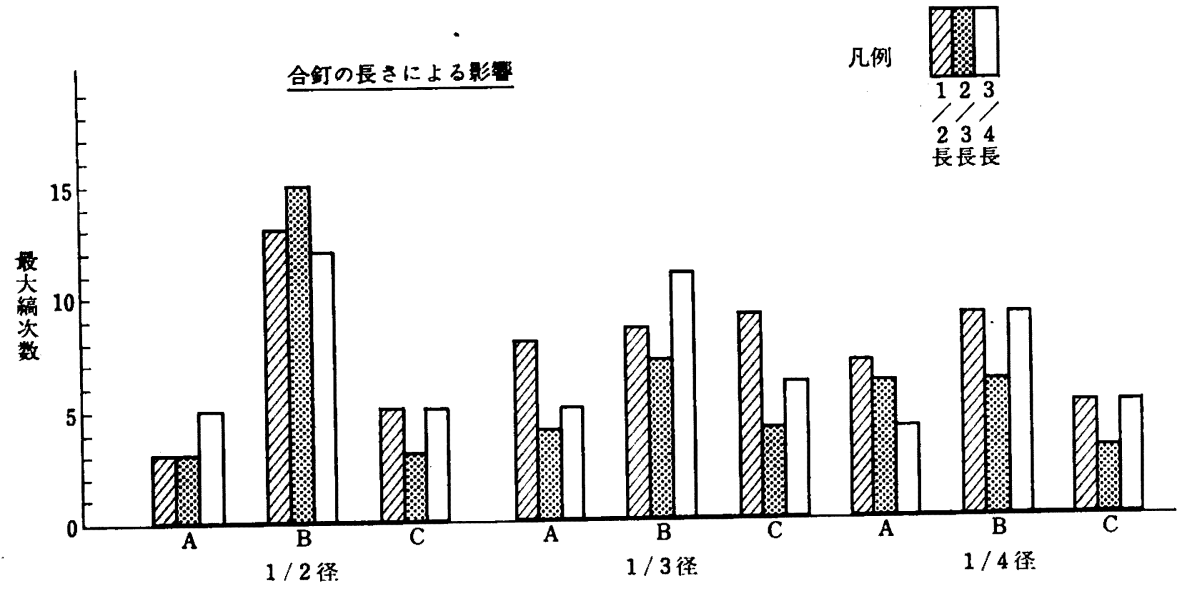

表 4

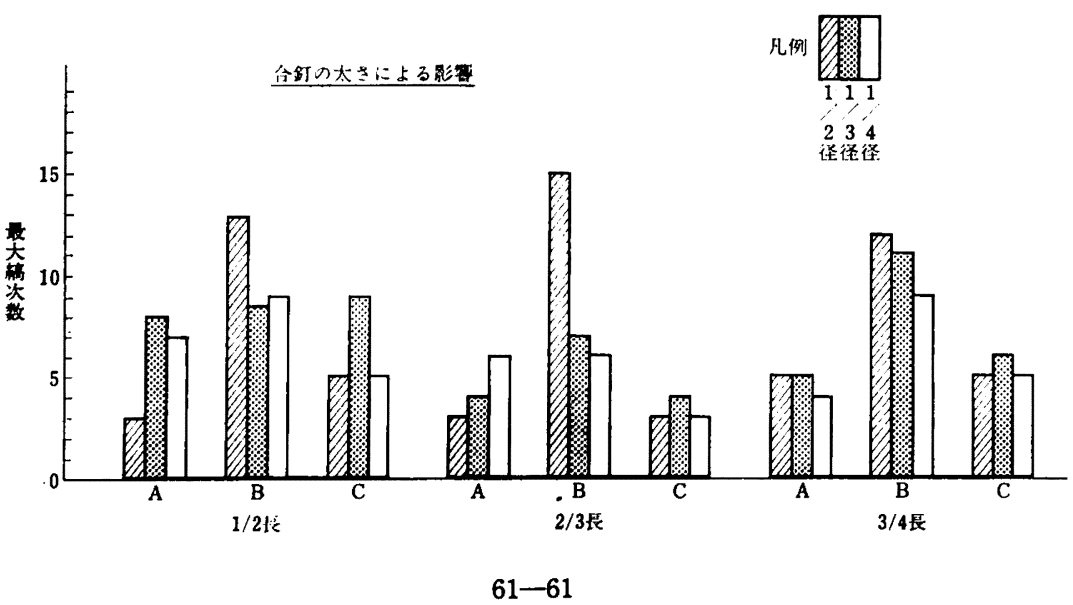



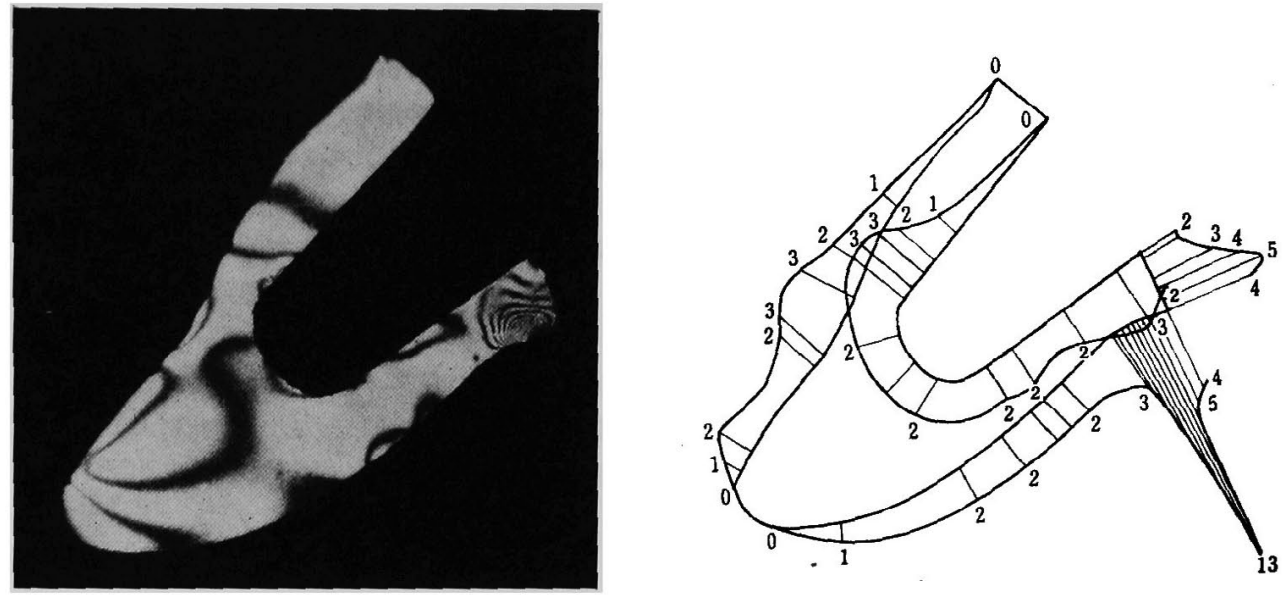

図 $7 \quad$ 1/2 径 1/2 長の合釬の等色線縞写真(左)とその周辺応力分布図（右）
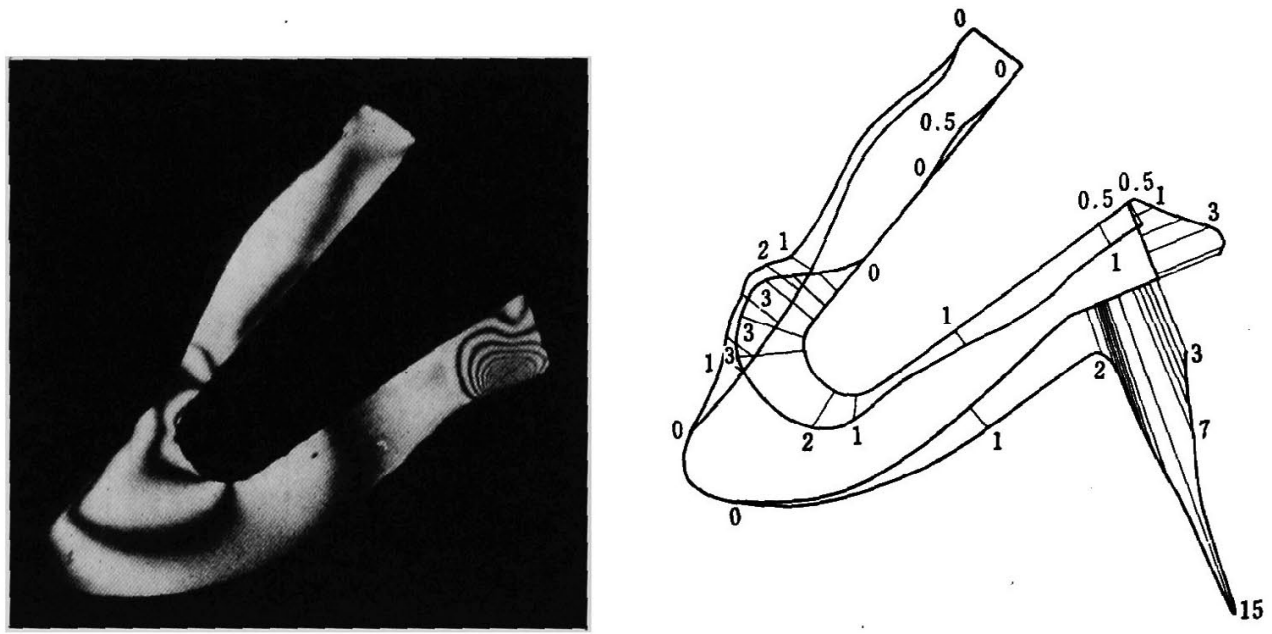

図 $81 / 2$ 径 $2 / 3$ 長の合釘の等色線縞写真（左）とその周辺応力分布図（右）

(2) $1 / 2$ 径 $2 / 3$ 長

図8のごとく, Aには $\mathrm{f}_{0} 3, \mathrm{~B}$ には $\mathrm{f}_{0} 15, \mathrm{C}$ には $\mathrm{f}_{0}$ 3である，Bにおいては（1）よりさらに大きな応力集中 を示した.

(3) $1 / 2$ 径 $3 / 4$ 長

図 9 のごとく, Aには $\mathrm{f}_{0} 5, \mathrm{~B}$ には $\mathrm{f}_{0} 12, \mathrm{C}$ には $\mathrm{f}_{0}$ 5 である. Aの応力集中は (1)，(2) より増大し，Bの忘 力集中は (1), (2) より減少している.

(4) $1 / 3$ 径 $1 / 2$ 長

図 10 のごとく, Aには $\mathrm{f}_{0} 8, \mathrm{~B}$ には $\mathrm{f}_{0} 8.5, \mathrm{C}$ には fo 8.5 である. A, B, C ともに大きな応力分布を示し た.
(5) $1 / 3$ 径 $2 / 3$ 長

図 11 のごとく, Aには $\mathrm{f}_{0} 4, \mathrm{~B}$ には $\mathrm{f}_{0} 7, C$ には $\mathrm{f}_{0}$ 4 で, 特に A, C の応力が減少した.

(6) $1 / 3$ 径 $3 / 4$ 長

図12のごとく,Aには $\mathrm{f}_{0} 5, \mathrm{~B}$ には $\mathrm{f}_{0} 11, \mathrm{C}$ には $\mathrm{f}_{0}$ 6 で，特に Bの応力が増大した.

(7) $1 / 4$ 径 $1 / 2$ 長

図 13 のごとく，Aには $\mathrm{f}_{0} 7, \mathrm{~B}$ には $\mathrm{f}_{0} 9$ ，Cには $\mathrm{f}_{0}$ 5 で，A，C に大きな応力集中がみられた。

(8) $1 / 4$ 径 $2 / 3$ 長

図 14 のごとく，Aには $\mathrm{f}_{0} 6$ ，Bには $\mathrm{f}_{0} 6$, Cには $\mathrm{f}_{0}$ 3 で, 各部の応力分布状熊としては (5) に近いが, Aに て 1.5 倍の応力集中がみられた. 

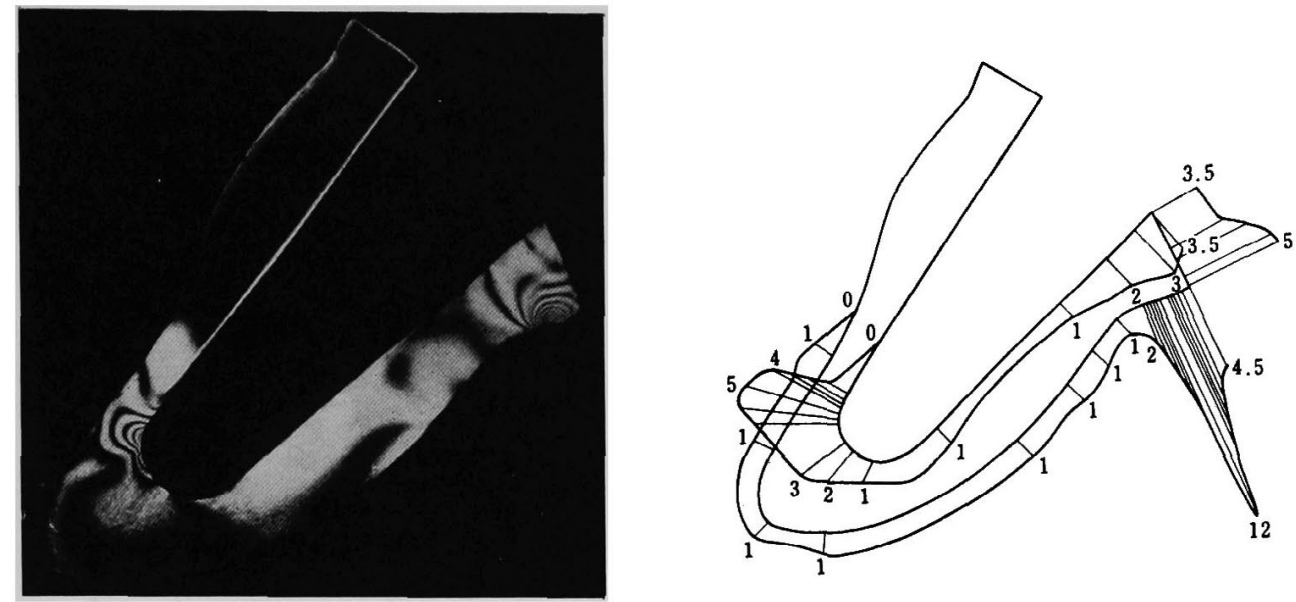

図 $91 / 2$ 径 3/4 長の合釘の等色線編写真（左）とその周辺応力分布図（右）
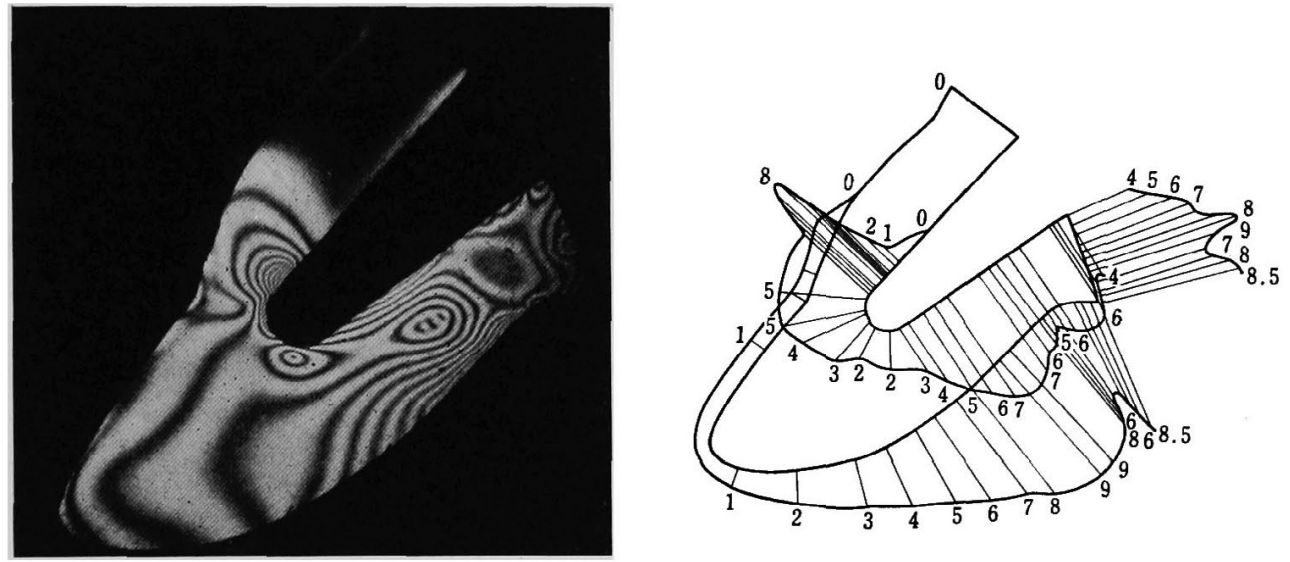

図 $101 / 3$ 径 $1 / 2$ 長の合釘の等色線縞写真（左）とその周辺応力分布図（右）
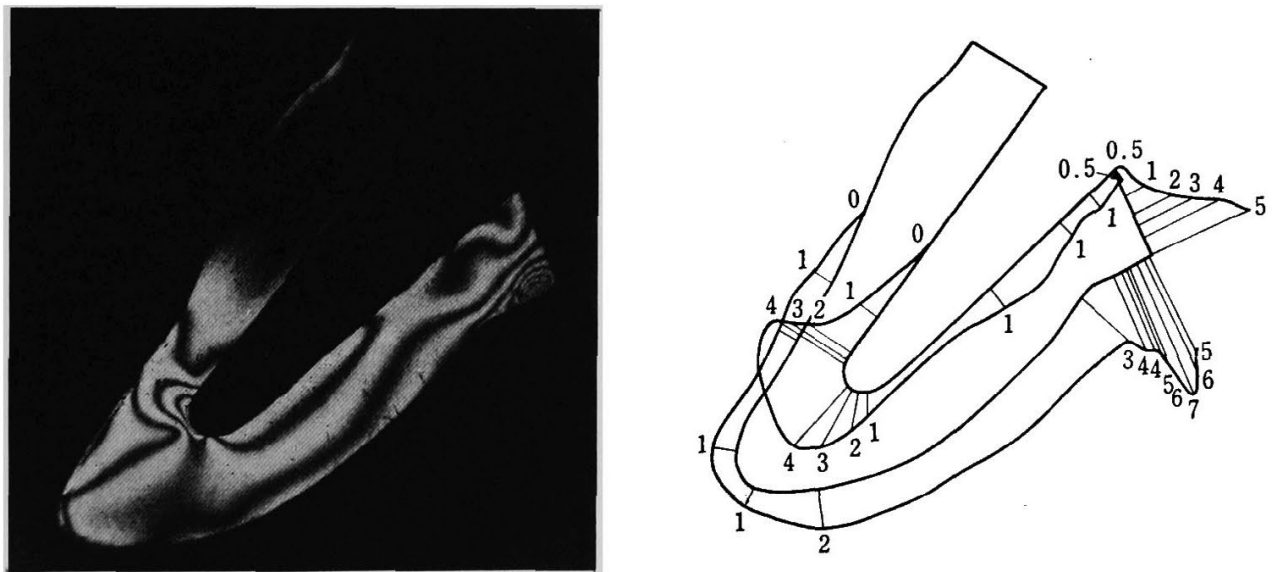

図 $111 / 3$ 径 $2 / 3$ 長の合釘の等色線縞写真（左）とその周辺応力分布図（右） 63-63 

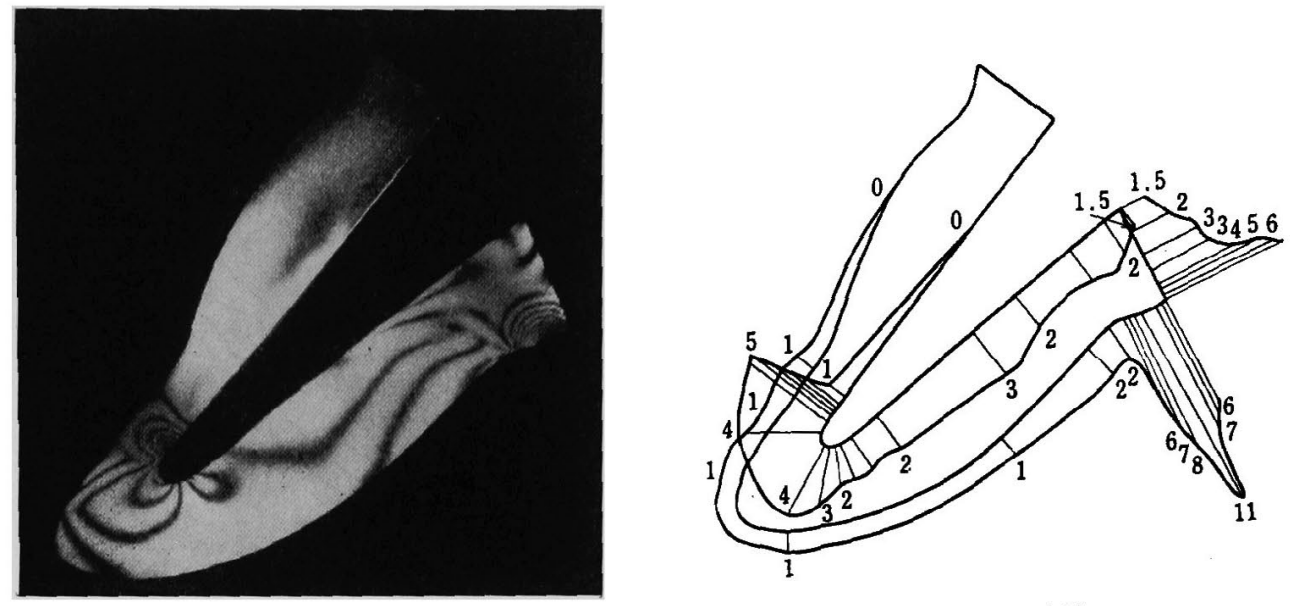

图 $121 / 3$ 径 $3 / 4$ 長の合釷の等色線編写真（左）とその周辺応力分布図（右）
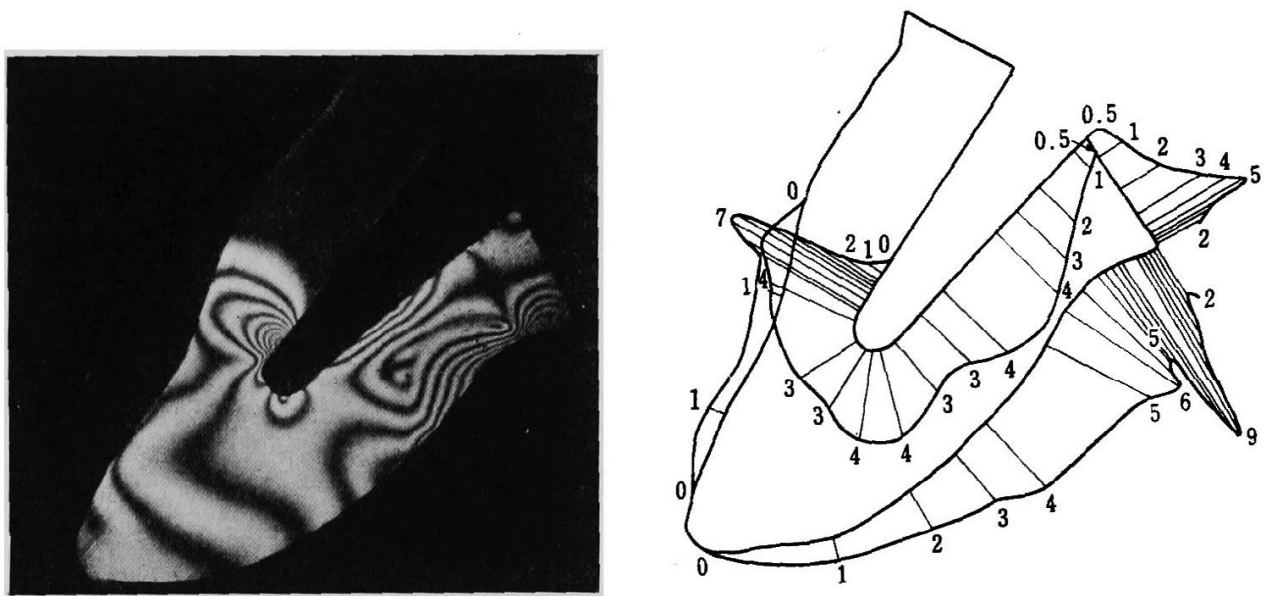

図 $13 \quad 1 / 4$ 径 1/2 長の合野の等色線編写真（左）とその周辺応力分布図（右）
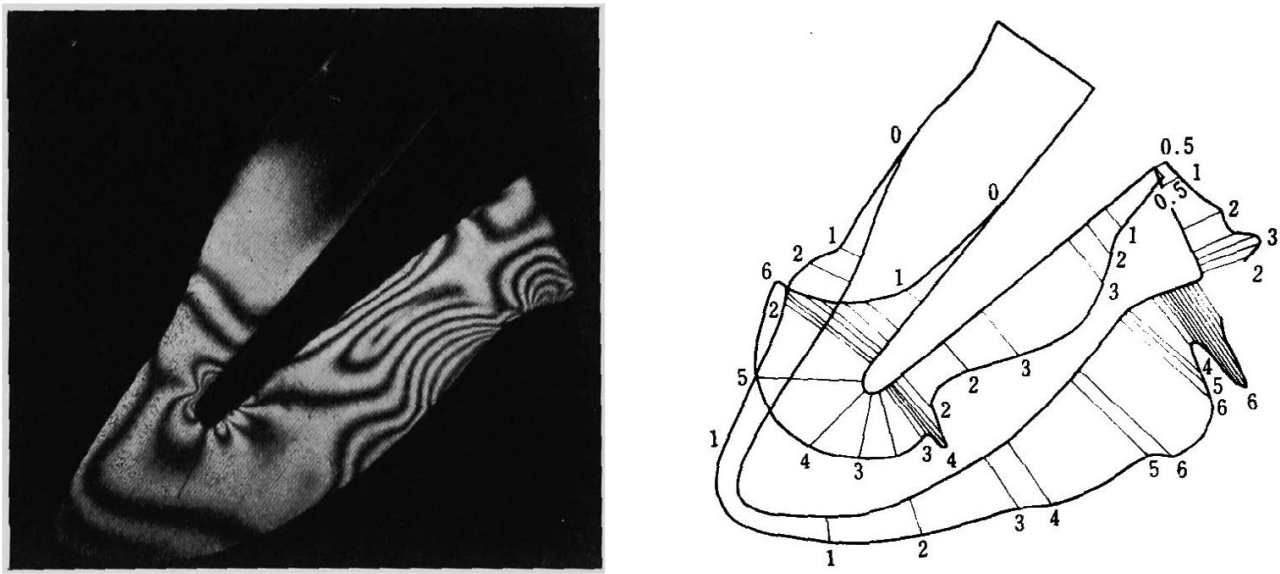

図 $141 / 4$ 径 $2 / 3$ 長の合釷の等色線繶写真 (左) とその周辺応力分布図 (右) 

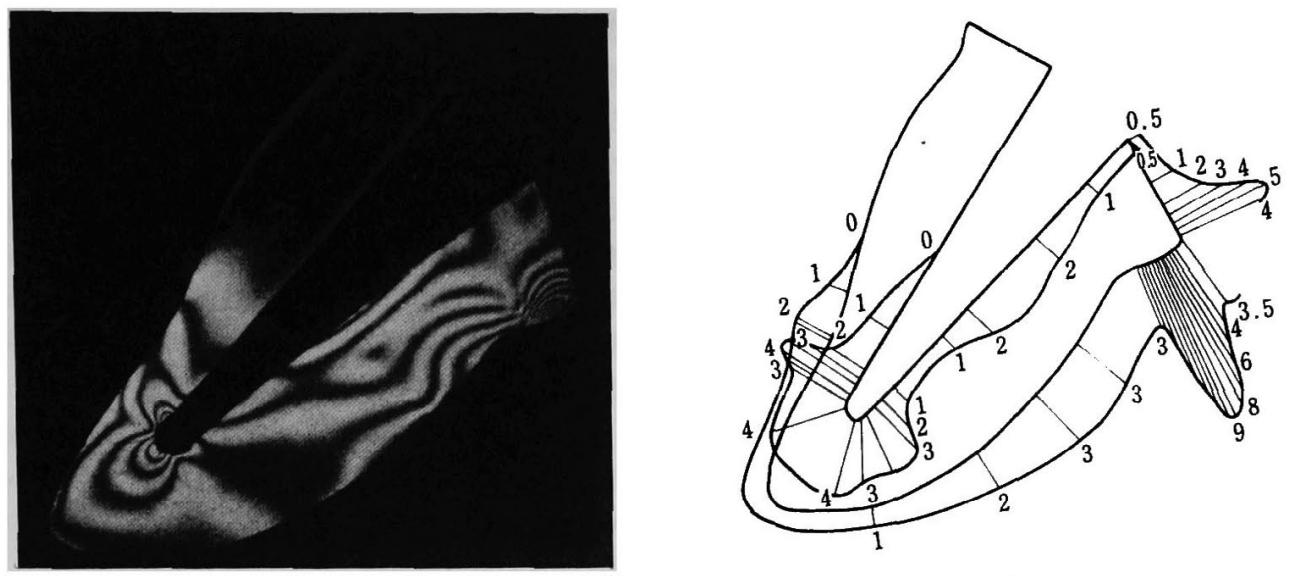

図 $151 / 4$ 径 $3 / 4$ 長の合釘の等色線綿写真（左）とその周辺灾力分布図（右）

(9) $1 / 4$ 径 $3 / 4$ 長

図 15 のごとく, Aには $\mathrm{f}_{0} 4, \mathrm{~B}$ には $\mathrm{f}_{0} 9, \mathrm{C}$ には $\mathrm{f}_{0}$ 5 で, Aの応力が減少した.

\section{IV. 総括および検討}

継続者ならびに Cast core の臨床的価值はいまさら述 ベるまでもなく，その使用頻度も高い17). 一方, その抱 える問題点も多く, ことに脱落, 歯質の破折, 臨床上の 操作性について解決されなければならない点が末だに多 w.

根管内に深く挿入された合釘の維持力と支台歯の保護 との問には，全く相反する点もあり，また互いに助長し 合つている点もあり,これらのことを全く分離して考え ることは不可能であり，意味のないことである.すなわ ち, 歯根という有限体の中で合猃が十分維持され，かつ 歯質を十分保護していなければ合釘の機能は果たし得な い.しかしながら，過去の合釘に関する研究には，これ らの点を結びつけ相互に検討した報告はないそそこで著 者らは, 可及的に歯根の形態を付与した支台歯模型に各 種の合釷を挿入し，荷重に対する応力の分布状態を観察 し, 支台歯の保護および合釷の維持安定に対する検討を 行なつた.

\section{S. type と R. type について}

合釘の先端の形状の差異による影響をみるために，予 備実験として S. type と R. type の比較を行なった.

従来, 保存修復学の立場から修復物 (Inlay) の安定効 力は, G. V. Black が初めて唱えた box-form の窝洞 形態にある18) とされている. 西塚 ${ }^{19)}$ はベクトルにより 数值計算を行ない, box-form 㸗洞の理論的裏付けを行
なつている. 渡辺 ${ }^{2022)}$ は光弾性実験により厘型窩洞 （box-form）と円形窩洞を比較し, 明瞭な窩底の隅角部 に発する応力は, インレー体の転覆を阻止する安定形態 としての保持効力として作用し，窩底を円形とすること は保持効力を殺诚する以外, 窩壁の保護にはなんらの意 義もないと述へている. しかし, 構造力学上, 一般に応 力集中という現象は好ましくなく，たとえそれが安全率 の中に含まれていたとしても, ときには疲労や衝撃のた めに破壊され安全性が脅かされることさえ起こつてくる ので23), 円形窩洞は䈑壁の保護という面では, 十分な意 義を有するものである.また，明膫な隅角部に発生する 感力集中を転覆の阻止力と考えるのはむしろ誤りであっ て, 同じ転覆に対する抗力を発揮させるなら小さな面積 より大きな面積で発揮させた方が小さな応力の発生です み, 破折に対する安全性を確保しつつ転覆を阻止するこ とが可能であろう.したがつて,インレー体の転覆阻止 に対する保持効力を問題とする場合には, 応力集中の度 合を比較するのではなく，応力の総和すなわち抗力の大 小を考えるべきであろう、一方，インレーと合制とは本 質的に置かれている情況が異なり, 合釘の場合窝底より もはるかに側壁の方が長く, 西塚の言う離脱させる分力 は全て側壁によって抵抗される.側壁によって抵抗され ていることは, R. type でも BおよびCの応力の相和が S. type の相和とほぼ同程度であることからも推察され る. また, 応力集中の強く現われる合釷の先端付近は, 歯根が解剖学的にほぼ円錐形であるため, 歯質の絶対量

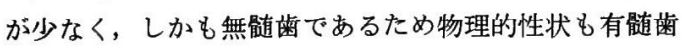
よりやや脆弱になつていくと考えられ ${ }^{24)}$, 歯質の保護と いら立場から合釘先端部に応力が集中することは好まし くない. したがって, 合釷においては, インレー窩洞の 
概念からいたずらに合釘先端の形態を角状にしてはなら ないと言えるであろう.

\section{2. 合釘の長さおよび太さについて}

上影中切歯を舌側から歯軸に対し $45^{\circ}$ 方向で荷重する と，Bおよび舌側根尖に応力が生じることは矢島25)の報 告から理解しうる.また, cast core を利用した補緅物 を装着した踩牙を同条件で荷重した場合も，歯全体とし ての動きには大して変化ないであろらが，合釗自体が支 台歯根内でどのように作用するか, また，合釘の長さ， 太さの変化が応力分布にどのように影響するか問題であ る. 本実験における応力の分布傾向は，A，B，Cの部位 に強い応力集中が発生し, 舌側の支台歯根面ならびに舌 側歯根上部にはほとんど応力分布が認められない.こう した応力分布状態は, 支台歯根内における合釷の動きを 推察する上で大きな手掛かりとなる.

歯軸に対し $45^{\circ}$ の方向から切端に荷重 F を与えると， 歯軸に直角の方向の分力 $F_{1}$ と歯軸方向の分力 $F_{2}$ に分 解される (図 5 ). $F_{2}$ は歯牙を歯軸方向に推進させ, 歯 槽窩全面で受け止められる. $F_{1}$ は歯牙に回転モーメン トを生じさせることになる。すなわち，唇側歯頖部付近 の歯槽骨および歯根膜が歯軸に直角かつ反対方向の抗力 を生じここの付近を支点として根尖部が舌側の方へはね 上がり，さらにその付近の歯槽骨および歯根膜から反対 方向の抗力が生じる. $\mathrm{F}_{2}$ は歯槽㸗全面で受け止められ るので, その応力は小さくなる. これらは補緅処置の施 されていない歯の運動を推察したものであるが, cast core を利用した補緅物が装着されている場合には, さら に歯根内で補緅物の運動が生じるものと思われる.すな わち, 今回用いた金属とエポキシ樹脂のヤング率は約 40:1であり, 臨床を想定した場合でも金属26) と象牙 質 ${ }^{27)}$ との比率は約 10:1 であるから，支台歯模型あるい は歯根の歪みが原因となつて運動が生じるであるう。合 猃ならびに補緅歯冠部は $45^{\circ}$ 荷重に対して歯軸に直角方 向の $F_{1}$ と歯軸方向の $F_{2}$ とに分解され, $F_{2}$ に対する抗力 は根面と合釘の側面および下端面によつて発揮される.

$\mathrm{F}_{1}$ によつて唇側根面の唇側寄りの部分を支点として回 転モーメントが生じ，舌側の合釘下部でははね上がりが 生じ，それより上の合釘舌側面は引き抜かれており，こ れは丁度くぎ抜きでくぎを引き抜く時の原理と同じであ る.しかし，実際には $F_{1}, F_{2}$ が同時に作用するので純 粋な回転運動ではなく，推進運動とともに回転中心が移 動しながら回転しているものと思われる.

以上は本実験より得た応力の分布状態から, cast core を利用した補緅物を装着した歯および補緅物の動きを推
察したものであるが，舌側根面は回転モーメントに何等 抵抗を示さず，むつぱら抵抗しているのは合釷の周壁な らびに唇側根面である.したがつて，両斜面形態は合釘 の長さをより長く保存しうるということで，理にかなつ た根面形態であると言えるだろう．また，舌側根面に有 効な補助維持装圆が付与されれば，回転モーメントに抵 抗し，AおよびCの応力集中を減少し，脱落防止および 歯質の保護に貢献するであろうことは村岡 ${ }^{13,28)}$ も示唆し ているところである.

このように, 維持力と応力の分布状態とは密接な関係 があり，全く別の範疇ではない，照井 ${ }^{29,30)}$ は crown や post crown など歯冠修復物の保持力は, 支台歯の傾斜 度，高さおよび鋳造体と鿖壁の面アラサに関係している と述べているが，このことはとりもなおさず支台歯と修 復物の摩擦抵抗あるいはセメントの剪断抗力をいかに発 揮させるかということにほかならない.

著者らの実験成績を総括的に眺めてみると，Aにおい て同一長さの合釘では太くなるにつれて応力集中が減少 し，同一太さの合釘では長くなるにつれて減少してい る. Bにおいて同一長さでは太くなるにつれて応力集中 が増加し, 同一太さでは $2 / 3$ 長が最も少なくなつてい る.またCにおいて同一長さでは $1 / 3$ 径に強く応力集中 がみられ，同一太さでは $2 / 3$ 長が最も少なくなつてい る.

すなわち，Aにおける合釘の寸法の変化の影響は，合 釘先端のはね上がりが太く長いほど抑制されるためで, Bにおける影響は，合钉が太くなるほど根面の面積が少 なくなり, 荷重方向への沈みに対する摩擦抵抗が減少す ることと，太くなるほど B 周辺の材質（歯質）が少なく なり, 応力の拡散ができなくなる31) ために応力集中は増 大する，また，長さに対する変化として，合釗が $1 / 2$ か ら 2/3 と長くなると合猃の広、範囲で力を負担するため 応力集中は減少するが, 逆に合猃が $2 / 3$ から $3 / 4$ と長く なると增大するのは, 合釘先端のはね上りが強く抑制さ れているため回転中心が合釘基部の方に移動し，そこか ら Bまでの距離も短くなるので, テコの原理で増大する ものと考えられる.Cにおける合釷の太さの影響忙, 合 釘が太いほど回転モーメントに抵抗するので $1 / 3$ 径より $1 / 2$ 径の方が応力集中が少なくなるが, 逆に $1 / 4$ 径とさ らに合釘が細くなると減少するのは, 回転モーメントを 受ける唇側根面の面積が大きくなり，合釷基部からCま での距離が大きくなることと, 応力の拡散が起こるため と考えられる. また, 長さの影響については, 1/2から $2 / 3$ と長くなると回転モーメントが抑制され応力集中が 
堿少するが，逆に $2 / 3$ から $3 / 4$ とさらに長くなると合釷 先端のはね上がりが一層抑制されるため回転中心が合釷 基部のほうに移動し，Bに括けると同様にテコの原理で 动力集中は大きくなるものと考えられる.さらに注目す べき点は，AおよびCに强い応力集中がみられるものに はBに応力集中が減少し，AおよびCに応力集中が少な い場合にはBに強く応力集中がみられるという相関の傾 向を示すことである.このことは，主に回転モーメント が生じている場合には，荷重方向一の沈みに対する抗力 が引張り応力と相殺し合つてBにおける応力が減少し， 主に回転モーメントが抑制されている場合には，相殺度 が小さいためBに応力が強く出現するためと考えられ る.

このように考えてくると，太く長い合釷ほど表面積が 大きく，摩擦抵抗も大きくなり回転モーメントに対し安 定するためAにおける応力集中心最も少なくなるように 思われるが，実際には3/4 長の合猃において太くなるに つれて、1/2 径の合猃においては長くなるにつれて増加 の傾向を示した.これは解剖学的形態からさらに不利な 状態に置かれ，AおよびB.周辺の材質(歯質)が少なく， 歯根周辺に近接するため応力の搪散ができずに応力が增 大するものと考えられる.

以上の上うに, 合釘の長さ, 太さの変化は A, B, Cの 各部位に生じ応力の分布状態に微妙に影響を与え， か つある関連性を持ちながら変化している. 特定の部分の 忘力集中を極力少なくしょうとすると他の部の応力集中 がその分增大し，かえつて不利な状態に置かれてしまう ことがある．また，合釘周囲の歯質の量がある限度を越 えて少なくなると，応力の拡散が阻まれ，むしろ応力集 中を增大させるようになる．したがって，合釷は長く太 いほど良いという従来の概念は否定されなければならな いであろう。そこで，われわれが合釘を臨床上応用する 際には，齿質を保護するという観点から A, B，Cにバラ ンスよく応力を分散するような合釘の形態, 寸法を選択 すべきである.このことは以上考察してきたように, 維 持安定性にも相通ずるものである.

著者らの行なつた二次元光弾性実験から，合釷の太さ は歯根幅の $1 / 3$ ，長さ㴹根長の $2 / 3$ に設定すべきで， 多くの先人たちが提唱していたことと符号することは興 味あるところである.

今回は二次元光弾性実験であつたが，実際の歯は立体 構造をなし，歯根は環状体をしているわけで，唇側の圧 縮応力は舌側の料澌の引張り応力によつて干涉され，本 実験とはやや異なつた応力分布を呈するであろうことは
予測に難くない，一方，立体的構造の合釷周壁面積も，二 次元的周用面積よりはるかに増大する. そういう意味で は，二次元的実験は実際よりもさらに苛酷な状態で行な われたと言えるであろう。

合釘の支台歯形成に際し，その対象となる菌根が歯槽 骨内に埋入しているため, X線写真, 根管長の測定など を参考としてもその形態，方向などを適確に把握するこ とができず，穿孔，歯質の破折; 脱落など遇発事故が常 につきまとう。一方, 合猃を利用した補緅物の追跡調查 によると，適当な長さと太さを有するものはむしろ少な 、32)。 それは，支台歯形成時の遇発事故遭遇化対する術 者の不安, 印象に続く一連の臨床操作性の困難さからく るものであろう.そういう意味では, Kurer Anchor System $^{33,34)}$ などはその先取りをしているものと言えよ う.しかし，その抱える問題性も大きい.そこで，著者 らは，合釘の長さが短くても維持力を損わずかつ良好な る応力分布を呈する合剑形態を染索するため，セメント の種類, taper 度, 補助維持装置などの要素を組合わせ, 維持力試験, 光弾性実験などを行なうことが今後の課題 であると考えている.

\section{V. 結 論}

著者らは，可及的に解剖学的定形と思われる歯根形態 を付与した両斜面形態の支台歯模型に, 合猃先端の形態 (S. type, R. type), 長さ, 太さをそれぞれ変えた合釷 （歯冠部を含む）を装着し, $45^{\circ}$ 方向から静的荷重を行 ない, 二次元光弾性実験により応力の分布状態を観察 しそそれぞれの比較検討を行なつて以下の結論を得た。

1. 合釬先端の角状の形態は, 合釘周辺の舌側下部に 強い応力集中を㺃起し，他の部の応力集中を緩和するこ となく，さらに合釘周囲の残存歯質量および無䯣歯の物 理的性状を考慮すると, 合钉先端の角状の形態はその舌 側周囲の歯質を破折に導く危険性を有し, 合釘先端の形 態恃角状を避け丸状にすべきであろう。

2. 合釘周辺の舌側下部, 歯根周囲の唇側歯頸部付近 および唇側の支台歯根面のそれぞれに応力を均等にかつ 小さく分布させることは，合釘の維持力の面からも，ま た歯質の破折防止の面からむ重要であり，本実験に㧍い ては, 長さ歯根長の $2 / 3$, 太さ歯根幅の $1 / 3$ の寸法の合 釷が，力学的㳊最を安定していると言える.

3. 回転モーメントに抵抗する有効なる補助維持装置 を舌側根面上に付与することにより, 合釘周辺の舌側下 部, 歯根周囲の唇側歯頸部付近および唇側の支台歯根面 
に発生する応力集中を緩和することができるものと考え られ，村岡 ${ }^{13,28)}$ による研究報告の妥当性をさらに裹付け たと言える.

4. 合釷下部の舌側周辺および合釷基部の唇側周辺の 歯啠をより多く保存することは，応力の拡散の助長によ り応力集中を減少させると同時に，応力に対する抵抗性 を增大させるので，歯質の破折防止の点で重要な要素で あると言える。

5. ほぼ正常な歯根形態を有する歯においては, 長さ 歯根長の $1 / 3$, 太さ歯根幅の 1/3 の寸法の R. type の合 釷を用いることによつて, 力学的安定が得られるものと 思われる.

稿を終わるに臨み, 理工学的立場からご指導ご校閲をいただ いた日本大学理工学部長尾弘教授に梁く感謝の意を表します. なお, 本研究の要旨は第 26 回日本大学崡学会総会 (1974 年 5 月 11 日)において発表したものをその会誌に抄録を揭载した.

\section{文献}

1) Koller, K.C. : Der Wurzelstift, Zahnersatz durch Kronen, Brücken und partielle Prothesen, Wien, 1954. Wilhelm Maudrich, S. 332 333.

2) Ackermann, H. : Grundsazliche überlegungen in bezug auf die mechanischen Belange der Stabilität der Stiftzähne, Schweiz. Mschr. Zahnheilk., 63 (8) : 799 805, 1953.

3）下総高次：継続齿；その維持力, 今日の補緅, 東京, 1960 , 医菓薬出版, 55 70.

4) 稻葉 : 継続菌の問題点, 日遴科評論, $327,89 \sim 98$, 1973.

5) Stern, N.: A direct pattern technique for posts and cores, J. Pros. Dent., 28 (3) : 279 283, 1972.

6) Colley, I.T., Hampson, E.L., Lehman, M.L. : Retention of Post Crowns, An Assessment of the relative efficiency of Posts of Different Shapes and Sizes, Br. Dent.J., 124 (2) : 63 69, 1968.

7）花村典之：継続歯合釷に関する研究（第1 報), 合釘の暁 み強さについて，日補緅誌，8:162 172，1964.

8）天野秀雄：継続蒾根面に加わる咬合力および咀嚼力に関 する研究, 日補緅誌, $14: 80 \sim 98,1970$.

9）出井義則：歯冠補緅物支台歯の力学的考察 (第 1 報), 歯 冠補緅物支台歯の光弹性実鈳, 崡科学報, $54: 411 \sim 420$, 1954.

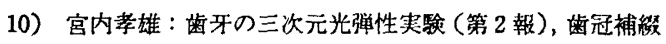
物支台歯の静力学的考察, 歯科学報, $59: 306 \sim 313$,
1959.

11) Standlee, J.P., Caputo, A.A., Collard, E.W., Pollack, M.H. : Analysis of stress distribution by endodontic posts, Oral surg., 33 (6) : 951 960, 1972.

12）藤田恒太郎：歯の解剖学, 東京, 金原出版, 1964 ,

13）村岡清孝: 継続歯の力学的研究 (その1), 各種根面形熊 にお付る二次元光弾性実験, 日補棳誌，16(2)：387〜 $399,1972$.

14）村岡清孝: 継続歯の力学的研究 (その3), 各種根面形態 における三次元光弹性実験, 日補綴誌，17(1)：45～63， 1973.

15）今村真作 : 邦人歯牙歯根膜幅に関する研究 (その1), 臨 床齿科, $12: 253 \sim 258,1940$.

16）辻 二郎, 西田正孝, 河田幸三: 光弾性実驗法, 東京, 日刊工業新閶社 (初版)，337 392, 1965.

17）宮内孝雄, 久保田英雄, 田中誠禾, 他: 最近の補緅臨床 の統計的観察，歯科学報，56(8): 322 328, 1956.

18）総山孝雄：保存修復 (充塓) 学総論 - 窩洞形成法, 東京, 永末書店, 112 145, 1969.

19）西塚忠義：インレー・ウワーク (Inlay-work)に就いて, 金属鐎筑䆚洞の力学的並びに数学的考察批判, $19(7,8$, 9) : 1 8, 46 48, 50 68, 72 77, 1926.

20）渡辺孝夫：金属インレ一窝洞の光弾性実酸による静力学 的考察 (その 1)，歯科学報, 55(10):376 380, 1955.

21）渡辺孝夫：金属インレ一窝洞の光弾性実験による静力学 的考察 (その2), 歯科学報, $56(2): 65 \sim 70,1956$.

22）渡辺孝夫：金属インレー窝洞の光弾性実験による静力学 的考察 (完), 歯科学報, 56(3): 107 116, 1956.

23）益田義治：入門光弾性実験，東京，日刊工業新開社（初 版), $18 \sim 26,1970$.

24）総山孝雄: 保存修復 (克荟) 学総論・䆓洞形成法, 東京, 永末書店, $151 \sim 156,1969$.

25）矢島忠夫：齿牙の光弹性実験 (第 2 報)，前业部断面につ いて，歯科学報，54(4)：121 130，1954.

26）花村典之：継綩歯合釘に関する研究（第 2 報)，合釘のテ 一只，長さの保持力に及ぼす影響について，日補悢誌， $8: 145 \sim 161,1964$.

27) Stanford, J.W., Weigel, K.V., Paffenbarger, G.C., Sweeney, W.T. : Compressive Properties of Hard Tooth Tissues and Some Restorative Materials, J.A.D.A., 60 (6) : 746 756, 1960.

28）村岡清孝: 継続歯の力学的研究 (その2), 各種根面形態 における二次元光弾性実験（特に補助維持装置の影響に つて), 日補緅誌，16(2):156 162, 1972.

29）照井保之：インレー保持に関する研究, 第 1 報, 鏻造体 による実験，日保存誌，14(2)：25～32，1972. 
30）照井保之：インレー保持に関する研究，第 2 報, 㞺合模 型による実験, 日保存誌, 14(2)：33 46, 1972.

31）小池国晃: Pin-Restoration の光弾性力学的研究, 第 3 報，模型板の外側辺縁からPin までの距離の影響，日補 緅誌, 17(4) : 422 444, 1974.

32）平沼謙二, 斉藤滋, 末次恒夫： $\mathrm{X}$ 線像による継続㧰の統 計的観察，第 1 報，一般的事項, 継続歯の樓造及び適合
状態について, 日補繝誌, 4(1):30 39, 1960.

33）水川一広, Kurer, P.F., 小池国晃, 松永俊雄: Kurer Anchor System について, 日歯科評論, $370: 1 \sim 19$, 1973.

34）大木一三, 水川一広, 小林栄作, 小池国晃, 松永俊雄, 他：Threaded Post, (第 1 報) 保持力, 保持物性, 適 合状態について, 31(5): 19 27, 1972. 